\title{
Impact of Brand Attributes on Consumers' Conative Attitude - A Study for Indian Apparel Industry
}

\author{
Sushil Raturi ${ }^{1}$ and Rakhi Raturi ${ }^{2}$ \\ ${ }^{1}$ Professor, Department of Fashion Management Studies, NIFT Mumbai, India. \\ ${ }^{2}$ Research Scholar, ITM University, India.
}

CITATION: Raturi, Sushil and Raturi, Rakhi (2019), "Impact of Brand Attributes on Consumers' Conative Attitude - A Study for Indian Apparel Industry”, MERC Global's International Journal of Management, Vol. 7, Issue 4, pp. 307-312.

ARTICLE HISTORY: Submitted: June 07, 2019, Revision received: July 20, 2019, Accepted: July 29,2019

ARTICLE TYPE: Research article

\begin{abstract}
The presence of a large number of apparel brands has made the apparel business highly competitive, with each brand exploring to provide something unique to the customer in product or service. The brands are trying to find out important attributes in a product that leads to the actual purchase of a product. The research attempts to provide answers to these concerns of the brand. The purpose of this study is to explore the key attributes of apparel brands which have an impact on the customers' purchase of the apparel brand. The main focus of this quantitative study is to measure the impact of Brand name, Brand personality, Brand satisfaction and Store image of an apparel brand on one of the aspects of customers' conative behaviour i.e. purchase. A questionnaire was prepared and pilot survey was conducted to finalize the questionnaire followed by data collection from one thousand customers. The finding of this study shows that brand name, personality and brand satisfaction have a significant relationship with purchase while the role of store image was found to be insignificant in influencing customers' purchase.
\end{abstract}

KEYWORDS: Brand personality, Brand satisfaction, Brand name, Store image, Conative.

\section{BIBLIOGRAPHY}

1. Aaker, J. L. (1997), "Dimensions of brand personality", Journal of Marketing Research, Vol. 34, No. 3, pp. 347-56.

2. Abernathy, F.; Dunlop, J.; Hammond, J. and Weil, D. (1999), A Stitch in Time: Lean retailing and the transformation of manufacturing: Lessons from the apparel and textile industries, New York: Oxford University Press.

3. Abhishek and Koshy, Abraham (2008), "Quality perceptions of Private Label Brands", Indian Institute of Management, Research \& Publication, W.P No: 2008-02-04, pp. 1-22.

4. Ailawadi, K.; Neslin, S. and Gednek, K. (2001), "Pursuing the value-conscious consumer: Store brand versus national brand promotions", Journal of Marketing, Vol. 65, pp. 71- 90.

5. Ajzen, I. and Fishbein, M. (1980), Understanding attitudes and predicting social behaviour, Prentice-Hal, Englewood-Cliffs, NJ.

6. Baidaray, Debjani (2011), "Changing face of Apparel Retail in India", Retail Biz, Volume 8, Issue 11, pp. 9-14.

7. Baldinger, A.; Blair, E. and Echambaldi, R. (2002), "Why brands grow", Journal of Advertising Research, Vol. 42, pp. 7-15.

8. Bhatnagar, G. (2004), "Retail Revolution", Indian Journal of Marketing, Vol. 34, Issue 11, pp. 24-31.

9. Bontems, Philippe ; Monier, Sylvette and Requillart, Vincent (1999), "Strategic effects of private labels", European Review of Agricultural Economics, Vol. 26, Issue 2, pp. 147-165.

10. Chakraborty, Samrat (2011), "Perceptions \& Buyer Behaviour Towards Private-Label Colas: An Exploratory Study to Understand the Views of the Store Managers of United Kingdom", The IUP Journal of Marketing Management, Vol. 10, Issue 1, pp. 5-18. 
11. Chintagunta, Pradeep K.; Bonfrer, Andre and Song, Inseong (2001), "Investigating the effects of store brand introduction on retailer demand and pricing behaviour", working paper, Graduate School of Business, University of Chicago.

12. Collins-Dodd, C. and Zaichkowsky, J. (1999), "National brand responses to brand imitation: Retailers versus other manufacturers", The Journal of Product and Brand Management, Vol. 8, Issue 2, pp. 96105 .

13. Fowler, D. and Clodfelter, R. (2001), “A comparison of apparel quality: Outlet stores versus department stores", Journal of Fashion Marketing and Management, Vol. 5, Issue 1, pp. 57-66.

14. Huitt, W. and Cain, C. (2018), "Human agency and the conative domain", in W. Huitt (Ed.), Becoming a Brilliant Star: Twelve core ideas supporting holistic education, pp. 105-122, La Vergne, TN: IngramSpark.

15. Keller, K. L. (1998), Strategic Brand Management: Building, Measuring, and Managing Brand Equity, Upper Saddle River, NJ, Prentice-Hall.

16. Nunnally, J. C. and Bernstein, I. H. (1994), "The Assessment of Reliability", Psychometric Theory, Vol. 3, pp. 248-292.

17. Schiffman, L. G. and Kanuk, L. L. (2004), Consumer Behaviour, Upper Saddle River, NY: Pearson Education. 